\title{
Microprocessor Complex Subunit DGCR8
}

National Cancer Institute

\section{Source}

National Cancer Institute. Microprocessor Complex Subunit DGCR8. NCI Thesaurus.

Code $C 92665$.

Microprocessor complex subunit DGCR8 (773 aa, $86 \mathrm{kDa}$ ) is encoded by the human

DGCR8 gene. This protein plays a role in the maturation of microRNA. 